\title{
CHRYSTOLOGICZNE PODSTAWY PROEKOLOGICZNEJ DZIAŁALNOŚCI KOŚCIOŁA
}

\author{
CHRISTOLOGICAL BASICS \\ OF PREECOLOGICAL ACTIVITY OF CHURCH
}

\begin{abstract}
The modern world was affected by an ecological crisis, which states a challenge for all the human race, as well as a sign of the times. Also the Catholic Church devotes in overcoming it, especially by the actions of catholic laity, which shape the temporal order. Christians find a supernatural motivation to be concerned about the created world in their faith. It is the person and creation of Jesus Christ himself. Because of his incarnation, He sanctified the material world, by entering into it. By accomplishing the work of salvation, not only did He deliver from taint of sins the people of all times, but also the whole creation. While residing on Earth, during his worldly life, He communed with nature and embraced it in a moral decent way. Incarnation, redemption and the attitude of Jesus make up a crucial premise for the whole activity of the Church.
\end{abstract}

Translated by Dawid Biesiadecki-Dziuba

Keywords: Jesus Christ; creation; Church; ecology.

Jednym z problemów, z którymi konfrontuje się współczesny świat, jest kryzys ekologiczny. Wspólnota Kościoła również stara się zaradzić owemu wyzwaniu współczesnego czasu. Dokonuje tego przede wszystkim poprzez zaangażowanie katolików świeckich, którzy uczestnicząc w kapłaństwie powszechnym i żyjąc w świecie, starają się kształtować porządek doczesny w duchu chrześcijańskim ${ }^{1}$. Najważniejszym impulsem do działania Kościoła, także

Ks. dr KRZYSZTOF WILCZKIEWICZ - prezbiter diecezji rzeszowskiej, doktorat z teologii pastoralnej w KUL w 2020 r., wykładowca teologii pastoralnej w Wyższym Seminarium Duchownym w Rzeszowie; adres do korespondencji: ul. Bursztynowa 1, 35-322 Rzeszów; e-mail: k.wilczkiewicz@o2.pl. ORCID: https://orcid.org/0000-0002-5067-6549.

${ }^{1}$ Wiesław Śmigiel, Uczestnictwo wiernych świeckich $w$ budowaniu Kościoła-Wspólnoty. Studium teologicznopastoralne $w$ świetle nauczania Kościoła (1962-2009), (Lublin: Wydawnictwo KUL, 2010), 20-21. 
w dążeniu do przezwyciężenia kryzysu ekologicznego, jest Boże Objawienie, a w nim w szczególny sposób Osoba i dzieło Jezusa Chrystusa. Przesłanka chrystologiczna stanowi właściwy punkt odniesienia dla każdego działania eklezjalnego.

Los całego stworzenia nierozerwalnie związany jest z Chrystusem, „bo w Nim zostało wszystko stworzone: i to, co w niebiosach, i to, co na ziemi, byty widzialne i niewidzialne, czy Trony, czy Panowania, czy Zwierzchności, czy Władze. Wszystko przez Niego i dla Niego zostało stworzone" (Kol 1,16). Papież Franciszek podkreśla, że Bóg w sposób tajemniczy wszedł w historię całego wszechświata, nie tylko stwarzając go poprzez swe Boskie Słowo i będąc źródłem Jego historycznego początku. To Słowo bowiem jest Drugą Osobą Trójcy Świętej, która przyjęła ludzkie ciało, a przez to stała się częścią materialnej sfery kosmosu. Obecność Boga przenika odtąd stworzenie niejako od wewnątrz, przy czym nie ogranicza to w jakikolwiek sposób autonomii rzeczy stworzonych ${ }^{2}$.

Świat w swoim wymiarze przyrodniczym stanowi przestrzeń dla spełnienia się relacji miłości pomiędzy Bogiem a Jego stworzeniem. Jest on przestrzenią umożliwiającą odwzajemnienie miłości Boga wobec stworzenia i stworzenia wobec Stwórcy. Celem istnienia świata nie jest wielość gwiazd i innych rzeczy stworzonych, lecz istnienie miejsca, w którym może zostać zawarte przymierze Boga i człowieka oraz wszystkiego, co istnieje. Świat stanowi przestrzeń dla „tak” miłości pomiędzy Bogiem a odpowiadającym mu człowiekiem i z nim całym stworzeniem. Ta odpowiedź miłości łączy się nierozerwalnie z przyjęciem i realizacją świętej woli Boga. Miłość Boga przybrała ciało i jest nią Jezus Chrystus. Wcielony Syn Boży w swoim ziemskim życiu objawia wartość świata stworzonego i godność człowieka. Poprzez swoją mękę, śmierć i zmartwychwstanie dokonuje dzieła zbawienia, zarówno człowieka, jak i całego stworzenia.

Przynajmniej od czasu Soboru Watykańskiego II Kościół coraz częściej wzywa uczniów Chrystusa do troski o świat stworzony. Rodzi się pytanie, jakie są podstawy teologiczne proekologicznej postawy chrześcijan? Celem tego opracowania jest wskazanie tych podstaw w chrystologii, a szczególnie w dziele wcielenia, odkupienia oraz w słowach i postawie Jezusa Chrystusa. W tym artykule będzie zastosowana metoda analizy treści posoborowego Magisterium Kościoła, a szczególnie nauczania papieża Franciszka. Po krótkim wprowadzeniu zostanie przedstawiona najpierw relacja wcielenia Syna Bożego do świata stworzonego, następnie wpływ dzieła odkupienia na świat widzialny, w końcu postawa Jezusa wobec świata. Opracowanie wieńczą syntetyczne wnioski.

\footnotetext{
${ }^{2}$ Franciszek, Laudato si', encyklika poświęcona trosce o wspólny dom (Kraków: Wydawnictwo M, 2015), 99.
} 


\section{WCIELENIE A ŚWIAT STWORZONY}

Niezwykła relacja, istniejąca pomiędzy Odwiecznym Synem Bożym a światem stworzonym, przejawia się $\mathrm{w}$ tajemnicy wcielenia. Prawdę tę podkreśla szczególnie św. Jan w prologu swojej ewangelii (por. J 1,1-18). W przekonaniu Benedykta XVI poprzez stwierdzenie, że Boże Słowo - Odwieczny Logos był na początku u Boga, a przez Niego wszystko się stało (por. J 1,2-3), Ewangelista nawiązuje do opowiadania o stworzeniu i dokonuje jego chrystologicznej interpretacji. Odwieczne Słowo, które stworzyło wszystko dla człowieka, samo stało się człowiekiem, pogrążając się w ludzkiej skończoności, czyli w stworzeniu, by ostatecznie doprowadzić do Siebie wszelką istotę żywą. Poprzez wcielenie rozpoczyna się nowe stworzenie, które w pełni objawia, kim jest człowiek oraz jaka jest rola świata stworzonego, innymi słowy odsłania ono odwieczne powołanie człowieka oraz świata, którego realizacja jest wolą Stwórcy ${ }^{3}$.

Dzieło inkarnacji polega na tym, że Druga Osoba Trójcy Świętej stała się człowiekiem, czyli zaczęła żyć i działać jako pełny człowiek. Osoba Boska złączyła się ściśle z ludzkim ciałem, które zostało wzięte z prochu ziemi, a przez to stanowi ono cząstkę naturalnego środowiska. W ten sposób ciało Jezusa Chrystusa, które stanie się narzędziem odkupienia człowieka, zaowocuje jednoczesnym odkupieniem całego stworzenia. Od chwili wcielenia istniejący dotąd podział świata na sfery sacrum, czyli świętości i profanum, czyli nieświętości nie ma podstaw. Cały wszechbyt, czyli wszystko co istnieje, od momentu inkarnacji jest święte, z wyjątkiem ludzkiego grzechu ${ }^{4}$.

Wcielenie jest wydarzeniem realistycznym. Bóg staje się człowiekiem w sposób najdosłowniej rzeczywisty. Bóg, będący źródłem i celem stworzenia, jego Stworzycielem i Zbawicielem, kroczy drogą zstępującą, prowadzącą do materii. Przez ten akt dokonuje się ponowna akceptacja świata w jego wymiarze materialnym. Bóg staje się bliski człowiekowi i całemu stworzeniu, oraz towarzyszy ich losowi i uczestniczy w nim. Jednocześnie ukazuje zbawczy sens ukryty w związku człowieka z materią. Implikuje to określony model dla kultury człowieka, w której jako konieczne jawi się otwarcie i szacunek wobec szeroko rozumianej cielesności, choć słabej i zniszczalnej, to jednak

\footnotetext{
${ }^{3}$ Benedykt XVI, Tajemnica Boga, który ma ręce i serce człowieka. Audiencja generalna. Watykan 9.01.2013, dostęp: 5.03.2020, https://opoka.org.pl/biblioteka/W/WP/benedykt_xvi/audi encje/ag_09012013.html.

${ }^{4}$ Roman Rogowski, Zwierzęta - nasi mniejsi bracia, dostęp: 06.03.2020, http://wiez.com.pl /2018/02 /09/zwierzeta-nasi-mniejsi-bracia/.
} 
akceptowanej i chronionej. Istnieje bowiem kenotyczna i nierozerwalna więź pomiędzy tym, co boskie, a tym, co materialne ${ }^{5}$.

Współczesne społeczeństwo lansuje w relacji człowieka do środowiska naturalnego biocentryczny model ekologiczny, który mówi o nadrzędnej roli przyrody samej w sobie i uznaje ją za jedyny czynnik regulujący funkcjonowanie świata stworzonego. Model ten wyraźnie koreluje ze scjentyzmem, sprowadzającym świat i człowieka do czystej natury w rozumieniu biologicznym i materialistycznym ${ }^{6}$. Podejście scjentystyczne można uznać za współczesną formę herezji gnostyckiej w wydaniu manichejskim, która podważała prawdziwość wcielenia Syna Bożego. Wynika stąd, że przyjęcie prawdy o inkarnacji Jezusa Chrystusa w świecie stworzonym i wynikająca $\mathrm{z}$ tego faktu wartość materii, jest nie do pogodzenia w ujęciu chrześcijańskim z działaniami proekologicznymi, u podstaw których leży biocentryzm ${ }^{7}$.

Prawda o wcieleniu stanowi syntezę łaskawości Boga oraz pokory człowieka i dzięki temu jest w stanie uchronić ludzką kulturę przed błędem antropologicznym. Pozwala ona na wpisanie antropocentryzmu w niezbędną dla niego sferę moralności, uwalniając go od despotyzmu, imperializmu czy grabieżczego wykorzystywania zasobów naturalnych świata przyrody, do czego prowadzi antropocentryzm bez etyki. Jednocześnie prawda o inkarnacji akceptuje zarówno duchowość i nieogarnioność życia człowieka, które ostatecznie pochodzi od Stwórcy ${ }^{8}$, jak i biologiczny wymiar egzystencji ludzkiej. Bowiem człowiek jest w równym stopniu istotą duchową, jak i biologiczną. Nieuwzględnienie cielesności i biologii stanowi swoisty wyraz pogardy wobec tego, co materialne, co ostatecznie podważa prawdziwość wcielenia i uznaje ją za działanie jedynie pozorne?

Wcielenie Syna Bożego dokonało się za sprawą działania Ducha Świętego (por. Łk 1,35). Jest On tym samym Duchem, który według opisu Księgi Rodzaju unosił się nad wodami w momencie stworzenia (por. Rdz 1,2). Benedykt XVI zauważa, że w ten sposób Ewangelista stwierdza, iż inkarnacja stanowi akt stwórczy, a jednocześnie wskazuje początek dzieła nowego stworzenia. „Gdy nasz Pan Jezus Chrystus został poczęty w dziewiczym łonie Maryi za sprawą Ducha Świętego, Bóg zjednoczył się z naszym stworzonym człowieczeństwem,

5 Jerzy Szymik, „Teologia wcielenia dzisiaj”, Śląskie Studia Historyczno-Teologiczne 47(2014), 2: 297-298.

${ }^{6}$ Andrzej Muszala, „Kwestie bioetyczne w encyklice «Laudato si'» papieża Franciszka”, Polonia Sacra 20(2016), 3: 51-52.

${ }^{7}$ Szymik, ,Teologia wcielenia dzisiaj”, 298.

${ }^{8}$ Tamże.

${ }^{9}$ Joseph Ratzinger, Bóg i świat. Wiara i życie w dzisiejszych czasach (Kraków: Znak, 2001), 278. 
wchodząc w nową, trwałą relację z nami i zapoczątkowując nowe stworzenie. Opowieść o zwiastowaniu ukazuje nam niezwykłą delikatność Boga. On nie narzuca się, nie określa z góry roli, jaką Maryja miała odegrać w Jego planie naszego zbawienia - najpierw stara się o Jej zgodę. W pierwszym stworzeniu oczywiście nie było mowy, by Bóg pytał o zgodę swoje stworzenia, ale czyni to w tym nowym stworzeniu. Maryja reprezentuje całą ludzkość. Odpowiadając na słowa anioła, mówi w imieniu nas wszystkich" ${ }^{10}$. Papież konkluduje swoje rozważanie stwierdzeniem, że tajemnica zwiastowania daje całej ludzkości, a więc i całemu stworzeniu, niezawodną nadzieję, że Bóg będzie nadal interweniował w historię świata i działał z mocą stwórczą.

Dzieło wcielenia Boga dokonuje przebóstwienia człowieka, a co za tym idzie, również przebóstwienia całego materialnego świata. Wejście Boga w świat stworzony zaowocowało wykształceniem nowej relacji łączącej Boga, człowieka i stworzenie, co z kolei powinno przekładać się na nowy sposób sprawowania władzy człowieka nad światem, które będzie naznaczone służbą i posłuszeństwem na wzór Chrystusa. W „przebóstwionym świecie” panuje zgoda, harmonia i wzajemna miłość. Bez niego świat byłby jedynie nieczytelnym chaosem. Od chwili inkarnacji władza Syna Bożego nad światem nie jest czymś zewnętrznym wobec świata, lecz tkwi w jego wnętrzu. Jezus, przyjmujący ludzkie ciało, uświęca świat materialny i podkreśla wyjątkową wartość materii. Jako sprzeczna $\mathrm{z}$ wiarą chrześcijańską jawi się postawa pogardy czy odrzucenia świata materialnego, gdyż postawa taka neguje w swej istocie prawdę o wcieleniu Drugiej Osoby Bożej ${ }^{11}$.

Jezus Chrystus, będąc prawdziwym Bogiem i prawdziwym człowiekiem, żyjąc i działając w świecie, podlega wszystkim uwarunkowaniom ludzkiej kondycji życiowej, także w odniesieniu do ciała. Trwa On w relacji ze światem przyrody. Spożywa On nie tylko chleb, ale i ryby (Łk 24,42). Jako wierzący Izraelita prawdopodobnie spożywał baranka paschalnego. Nie sprzeciwiał się składaniu ofiar w Świątyni Jerozolimskiej, zarówno w odniesieniu do płodów roli, jak i do ofiar krwawych ze zwierząt (por. Kpł 1-7). Na skutek egzorcyzmu dokonanego w Kraju Gadareńczyków pozwala demonom opanować stado świń, co ostatecznie doprowadza do śmierci tych zwierząt. Posłużył się oślicą, aby wjechać do świętego miasta, a pod jego stopy ścielano gałązki palmowe (por. Mt 21,1-10). Warto jednak zauważyć, że poprzez ofiarę ze

\footnotetext{
${ }^{10}$ Benedykt XVI, Dziękujmy Bogu za cud wcielenia: homilia podczas nieszporów w Bazylice Zwiastowania Pańskiego. Nazaret 14.05.2009, dostęp: 06.03.2020, https://opoka.org.pl/biblioteka /W/WP/bene dykt_xvi/homilie/zsw_nazaret_nieszp_14052009.html.

${ }^{11}$ Zdzisław Kijas, Początki świata i cztowieka (Kraków: Wydawnictwo WAM, 2004), 170-171.
} 
swego życia, Jezus zastąpi wszelkie ofiary składane dotąd ze zwierząt i roślin oraz zajmie ich miejsce sam stając się ofiarną żertwą (por. Hbr 9,11-10, 18) ${ }^{12}$.

\section{ZBAWIENIE W CHRYSTUSIE A ŚWIAT STWORZONY}

Starotestamentowy opis stworzenia człowieka i świata oraz powierzenie człowiekowi troski o świat stworzony należy widzieć w kontekście całego „wydarzenia Jezusa”, czyli w kontekście Jego wcielenia, życia, nauczania i zmartwychwstania. Pozwala to na odczytanie najgłębszego sensu panowania człowieka nad światem, a jednocześnie odsłania właściwe znaczenie powiązań, jakie istnieją między Bogiem, bliźnim a całym stworzeniem ${ }^{13}$. Na te relacje w szczególny sposób rzutuje grzech człowieka, gdyż skutkuje on również w świecie przyrody. Grzech, dotykając stworzenia, powoduje jego marność, prowadzi do zepsucia i śmiertelności. Św. Paweł wyraźnie stwierdza, że stworzenie zostało poddane skutkom grzechu ,nie z własnej chęci, ale ze względu na Tego, który je poddał - w nadziei, że również ono zostanie wyzwolone z niewoli zepsucia, by uczestniczyć w wolności i chwale dzieci Bożych" (Rz 8,20-21) ${ }^{14}$. Wyzwolenie to dokonało się w misterium paschalnym Jezusa Chrystusa.

Zmartwychwstanie Jezusa Chrystusa jest definitywnym, doskonałym i ostatecznym wydarzeniem pojednania człowieka z Bogiem ${ }^{15}$. Jest ono jednocześnie wydarzeniem o charakterze kosmicznym. Stanowi Bożą odpowiedź na potrzebę odnowienia całego stworzenia. Uwielbione ciało Zmartwychwstałego Pana stanowi gwarancję przemiany całego stworzenia. Chrystusowa rezurekcja, będąc największą i decydującą przemianą w świecie stworzonym, nie jest jedynie osobistym zwycięstwem Chrystusa, lecz rozlewa się na całe stworzenie, jako Boży dar, zaś relację Zmartwychwstały-stworzenie należy rozpatrywać w kategoriach soteriologicznych ${ }^{16}$. Zmartwychwstanie Chrystusa związane jest również z artykułem wiary, określonym w Credo jako „zstąpienie do piekieł". Chrystus zstąpił wówczas do serca wszechświata, do jądra stworzenia, by w ten sposób odkupić wszystko, co zostało przez Niego stworzone, całość

\footnotetext{
${ }^{12}$ Rogowski, „Zwierzęta - nasi mniejsi bracia”.

${ }^{13}$ Kijas, Początki świata i człowieka, 171.

${ }^{14}$ Roman Batorski, „Encyklika «Laudato si’» czytana przez biblistę”, w Kościót i nauka w obliczu ekologicznych wyzwań. Źródta, inspiracje i konteksty encykliki «Laudato si'», red. Jacek Poznański, Stanisław Jaromi (Kraków: Wydawnictwo WAM, 2016), 102-103.

${ }^{15}$ Marian Rusecki, Traktat o Objawieniu (Kraków: Wydawnictwo Księży Sercanów, 2007), 346.

${ }^{16}$ Jacenty Mastej, Staurologiczo-rezurekcyjna wiarygodność chrześcijaństwa (Lublin: Wydawnictwo KUL, 2009), 230-231.
} 
wszechbytu. Powstając z martwych w swoim ludzkim ciele, chociaż przemienionym, ale zawierającym cząstkę stworzenia, przyniósł zbawienie całemu rodzajowi ludzkiemu, a z nim każdemu istniejącemu bytowi ${ }^{17}$.

Zbawcza przemiana świata stworzonego zachodzi w środowisku ludzkiej egzystencji. Obliguje to człowieka do traktowania tego środowiska jako dzieła Bożego. Człowiek winien się do tego środowiska odnosić z szacunkiem. Nie może prowadzić rabunkowej eksploatacji bogactw naturalnych, dewastować go czy zanieczyszczać, gdyż takie działanie nie jest wypełnieniem Bożego zadania, jakim jest włodarstwo nad światem oraz bycie partnerem Boga w kształtowaniu świata. Chrześcijanin, będący ikoną Chrystusa, poprzez pełną szacunku postawę wobec dzieła stworzenia oraz działanie na rzecz ochrony środowiska, współdziała przez miłość w zbawczym misterium Boga ${ }^{18}$.

Zmartwychwstanie, będąc aktem Bożej miłości, prowadzi do usynowienia wszystkich ludzi (por. J 3,1). Człowiek staje się dzieckiem Bożym dzięki mocy działającego Ducha Świętego. Dzięki Niemu objawiony w Zmartwychwstałym Panu obraz Boga i człowieka może być ucieleśniany w każdym człowieku ${ }^{19}$. Przebóstwienie ludzkiej natury usynawia wszystkich ludzi dzięki łasce przybrania ${ }^{20}$, jaką człowiek na mocy zmartwychwstania otrzymuje w chwili chrztu świętego ${ }^{21}$. Na mocy Bożego synostwa człowiek staje się dziedzicem Królestwa Bożego (por. Rz 8,17; Ga 4,7). Synostwo Boże zostało objawione poprzez ziemską działalność Chrystusa. Podobnie synostwo Boże każdego człowieka realizuje się w czasie ziemskiej egzystencji, a wypełni się w czasach ostatecznych ${ }^{22}$.

Zmartwychwstały Jezus odniósł pełne zwycięstwo nad szatanem, grzechem i śmiercią. Każdy człowiek, od chwili grzechu pierworodnego, żył w stanie nieprzyjaźni z Bogiem (por. Rz 5,10). Dysharmonia panowała w relacji

\footnotetext{
${ }^{17}$ Rogowski, „Zwierzęta - nasi mniejsi bracia”.

${ }^{18}$ Marian Rusecki, Pan zmartwychwstat $i$ żyje: zarys teologii rezurekcyjnej (Warszawa: Instytut Wydawniczy PAX, 2006), 256.

${ }^{19}$ Tadeusz Dola, Teologia misteriów życia Jezusa (Opole: Wydział Teologiczny Uniwersytetu Opolskiego, 2002), 280-281.

${ }^{20}$ Warto zaznaczyć, że istnieje różnica między relacją Boga-Ojca z ludźmi a relacją Boga-Ojca z Jego Synem. Relacja Jezusa z Ojcem jest relacją ontyczną, płynącą z faktu boskiej natury Jezusa. Z kolei Boże synostwo ludzi wypływa z łaski przybrania, wysłużonej przez Chrystusa, a ludziom udzielanej mocą Ducha Świętego. Henryk Seweryniak, Świadectwo i sens. Teologia fundamentalna (Płock: Płocki Instytut Wydawniczy, 2001), 228.

${ }^{21}$ Za synów Bożych, obok ochrzczonych, należy uważać także nieochrzczonych, w których zamieszkała Boża łaska przybrania. Andrzej Dańczak, ,Zmartwychwstanie umarłych jako jeden z dynamicznych wymiarów eschatologii”, Verbum Vitae 15(2009): 355-357.

${ }^{22}$ Tenże, „Nadzieja zakotwiczona w Bogu. O eschatologii encykliki «Spe salvi»”, Studia Gdańskie 23(2008): 82-89.
} 
człowieka do siebie samego i całego stworzenia, gdyż człowiek był niewolnikiem grzechu. Jednocześnie nie był w stanie samodzielnie uwolnić się od niego

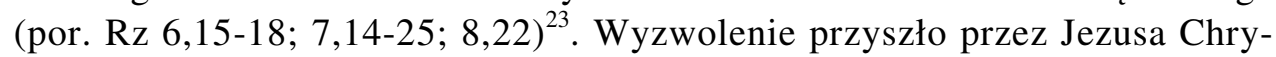
stusa, który każdego człowieka uwolnił od grzechu i śmierci (por. 1 Kor 15,54-57; Rz 8,31-39; Hbr 2,14-15) ${ }^{24}$. Moc Chrystusowej rezurekcji nie ogranicza się jednak tylko do człowieka, lecz zapowiada los całego stworzenia. Jakościowa przemiana Jezusowego ciała, dokonana w czasie powstania $\mathrm{z}$ martwych, jest początkiem przemiany, która swą pełnię osiągnie w czasach ostatecznych ${ }^{25}$. Papież Franciszek stwierdza, że od chwili zmartwychwstania, stworzenia nie stanowią jedynie części rzeczywistości naturalnej, gdyż Zmartwychwstały otacza je i ukierunkowuje do pełni. Każdy byt, który człowiek może podziwiać swoimi oczami, od Chrystusowej rezurekcji napełniony jest Bożą obecnościąa ${ }^{26}$.

Zmartwychwstanie Jezusa Chrystusa przywraca człowiekowi i całemu światu stworzonemu utracone pierwotne piękno. Boży obraz, który człowiek nosi w sobie od chwili stworzenia, zostaje zaś odnowiony. Podobnie ludzka natura zostaje odnowiona, a równocześnie przekształcona i usposobiona do włączenia się i trwania w życiu Bożym. W obrazie Zmartwychwstałego w pełni uwidacznia się to, kim jest Bóg, oraz to, kim jest człowiek. Objawienie to ma charakter personalny. Wyraża miłość Stwórcy wobec stworzenia. Miłość Boża nie wyczerpuje się jednak w zmartwychwstaniu Chrystusa. Poprzez akt odkupienia, dokonanego przez Chrystusa, człowiek zostaje wzbogacony zbawczymi darami, przez co przekracza godność płynącą z faktu stworzenia ${ }^{27}$.

Pomimo zbawczej i przemieniającej mocy płynącej z faktu zmartwychwstania, współczesny człowiek wydaje się żyć w „niezbawionym świecie”28, którego obraz zdają się kreślić: cierpienie z powodu niesprawiedliwości społecznej, wojny, głód, skrajne ubóstwo i nędza, nieuleczalne choroby, problem bezdomności oraz kryzys ekologiczny ${ }^{29}$. Taka sytuacja podkreśla fenomen

\footnotetext{
${ }^{23}$ Hugolin Langkammer, Życie człowieka w świetle Biblii. Antropologia biblijna Starego i Nowego Testamentu (Rzeszów: Poligrafia Wyższego Seminarium Duchownego, 2004), 200-203.

${ }^{24}$ Lucjan Balter, ,Nadzieja życia wiecznego skonkretyzowana w śmierci i zmartwychwstaniu Chrystusa”, Communio 4(1984), 4: 77-78.

${ }^{25}$ Krzysztof Wilczkiewicz, „Ekologia i zmartwychwstanie. Rezurekcyjna przemiana człowieka i świata jako podstawa proekologicznej troski Kościoła”, Rocznik Kolbuszowski 17(2017): 455.

${ }^{26}$ Franciszek, Laudato si', 100.

${ }^{27}$ Wilczkiewicz, ,Ekologia i zmartwychwstanie”, 455-456.

${ }^{28}$ Mastej, Staurologiczno-rezurekcyjna wiarygodność chrześcijaństwa, 234.

${ }^{29}$ Papież Franciszek podkreśla, że Ziemia: ,,protestuje z powodu zła, jakie jej wyrządzamy nieodpowiedzialnym wykorzystywaniem i rabunkową eksploatacją dóbr, które Bóg w niej umieścił. [...] Przemoc, jaka istnieje w ludzkich sercach zranionych grzechem, wyraża się również w objawach choroby, jaką dostrzegamy w glebie, wodzie, powietrzu i w istotach żywych. $Z$ tego względu
} 
misterium grzechu obecnego w świecie. W tym kontekście wiarygodność i autentyczność chrześcijan wypływa ze słów św. Pawła: „stworzenie z upragnieniem oczekuje objawienia się synów Bożych” (Rz 8,19). Chrześcijańskie świadectwo życia, opowiadanie się po stronie krzywdzonych i cierpiących oraz niszczonego środowiska stanowi uwiarygodnienie mocy Chrystusowego powstania $\mathrm{z}$ martwych, przemieniającego $\mathrm{w}$ doczesności egzystencje i postawy życiowe pojedynczych wyznawców Chrystusa ${ }^{30}$.

\section{POSTAWA JEZUSA WOBEC STWORZENIA}

Według nauczania papieża Franciszka Jezus, będący w relacji ze światem przyrody, nieustannie podkreślał łączność każdego stworzenia z Ojcem Niebieskim i Jego niezwykłą troskę o nie. Podczas rozmów ze swoimi uczniami zachęcał do rozpoznania ojcowskiej czułości i troski Boga, który troszczy się o każde stworzenie. Szczególnym przykładem owej troski było roztoczenie Boskiej pieczy nad wróblami oraz innymi ptakami powietrznymi (por. Łk 12,6; Mt 6,26). Wszystkie rzeczy istniejące stanowią również orędzie Boga Ojca dla innych stworzeń. Podziw wobec piękna, jakie nosi w sobie każdy byt, stanowi pierwszy krok na drodze odkrywania przesłania Boga w stworzeniu. Do tego zachęcał swoich uczniów sam Jezus, który jednocześnie dał jasny przykład podziwu dla przyrody w trakcie pielgrzymowania po swym ojczystym kraju (por. J 4,35). Znakiem żywego związku Nazarejczyka z przyrodą i Jego kontemplacyjnego nastawienia wobec niej było wykorzystanie w przypowieściach obrazów zaczerpniętych ze świata natury (por. Mt 13,31-32).

Ewangelista Marek, jako jedyny spośród autorów kanonicznych ewangelii, wzmiankuje w opisie kuszenia Jezusa na pustyni, że przebywał on ze zwierzętami. Szczegół ten nie występuje w żadnym z tekstów paralelnych. Chodzi w nim o dzikie zwierzęta, które zwykle stanowią zagrożenie dla człowieka. Harmonijne przebywanie Jezusa z niebezpieczną dla ludzi częścią stworzenia jest zapowiedzią nadejścia czasów mesjańskich, wprowadzenia prawdziwego pokoju, którego Dawcą jest Mesjasz, i realizacją proroctwa Izajasza (por. Iz 11,6-9; 43,20). Opis ten stoi niejako w opozycji do biblijnego obrazu pasterza, który miał za zadanie chronić powierzone mu stada. W trakcie

wśród najbardziej zaniedbanych i źle traktowanych znajduje się nasza uciskana i zdewastowana ziemia, która «jęczy i wzdycha w bólach rodzenia » (Rz 8,22)”. Franciszek, Laudato si’, 2.

${ }^{30}$ Dola, Teologia misteriów życia Jezusa, 275. 
przygotowania do pełnienia swej funkcji uczył się umiejętności potrzebnych

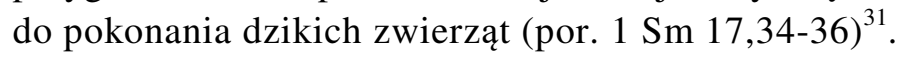

Grecka konstrukcja gramatyczna Markowego stwierdzenia, że „Jezus był ze zwierzętami”" (zwłaszcza gr. przyimek metá) sugeruje bliską, wręcz intymną wspólnotę, jaka na pustyni istniała pomiędzy Bogiem-Człowiekiem i dzikimi bestiami. Oznacza to, że wspomnienie o zwierzętach w opisie kuszenia nie jest jedynie zabiegiem wskazującym na okoliczności tego wydarzenia. Należy więc zwrócić uwagę na kontekst, w jakim znajduje się rozważany fragment. Opis kuszenia Jezusa wkomponowany został przez Ewangelistę w prolog Ewangelii, który prezentuje Jezusa jako obiecanego Mesjasza i Syna Bożego oraz ukazuje jego działo zbawcze. Prolog wzmiankuje również o osobie Jana Chrzciciela, który przygotowuje drogę dla Pana. Jan działa na pustyni, podobnie jak i kuszenie ma miejsce na pustyni, która jest przeciwieństwem ogrodu Eden i symbolizuje konsekwencje grzechu. Prorocy zapowiadali, że właśnie na pustyni rozpocznie się dzieło zbawienia, co spowoduje, że pustynia znów będzie ogrodem (por. Iz 35,1-3). Podobnie jak Duch Pański unosił się nad wodami w chwili stwarzania, tak nad Jordanem w chwili chrztu Jezusa unosi się Duch Boży, który zstępuje, by zapanowała harmonia w świecie. Jedność Boga i stworzeń oraz pokonanie szatańskich pokus to początek wypełnienia czasu, oznaczający nadejście Królestwa Bożego (Mk 1,15). Królestwo Boga ukazuje się w ten sposób nie jako coś nierealnego, lecz konkret relacji, jakie panują pomiędzy wszelkimi stworzeniami oraz stworzeniami a Stwórcą. Można zatem uznać, że wezwanie do nawrócenia (por. Mk 1,15) związane jest ze zmianą stosunku człowieka do świata zwierząt i całego środowiska naturalnego. Jezus, któremu służą aniołowie, przebywający ze zwierzętami na pustyni, pokonujący diabelskie pokusy, namaszczony Duchem Świętym w trakcie chrztu w Jordanie, właśnie na pustyni inauguruje na nowo królowanie Boga w swoim stworzeniu. Duch Święty, przekazywany przez Chrystusa (Mk 1,18: „On zaś chrzcić was będzie Duchem Świętym”), jest gwarantem i podstawą odbudowania pierwotnej harmonii między człowiekiem a wszelką istotą żywą ${ }^{32}$.

Ciekawą konstatację przedstawia w omawianej tu kwestii ks. Roman Batorski, który wskazuje, że papież z Argentyny nie przywołuje Markowego opisu o pobycie Jezusa ze zwierzętami na pustyni jako teologicznej podstawy do proekologicznej troski chrześcijan. Ponadto twierdzi, że Papież przedstawia

\footnotetext{
${ }^{31}$ Artur Malina, „Dlaczego Jezus był ze zwierzętami (Mk 1,13)? Odniesienie do zwierząt w Ewangelii Markowej”, Verbum Vitae 32(2017): 233-254.

${ }^{32}$ Batorski, ,Encyklika «Laudato si’» czytana przez biblistę”, 98-101.
} 
jako wzór harmonii ze stworzeniem osobę św. Franciszka z Asyżu, a nie wskazuje na uzdrowienie relacji ze stworzeniem, które urzeczywistniło się w życiu Jezusa Chrystusa - Nowego Adama. Tymczasem dopiero dzięki zbawczej mocy pochodzącej od Odkupiciela święci oraz wszyscy chrześcijanie są w stanie budować swoją jedność ze stworzeniem ${ }^{33}$.

Jezus w swoim ziemskim życiu nie przedstawia się jako wróg materii, wręcz przeciwnie, żyje w zgodzie i harmonii ze stworzeniem. Posłuszne są $\mathrm{Mu}$ żywioły przyrody (zob. Mt 8,27). Nie jest On przeciwnikiem rzeczy przyjemnych w życiu, a związanych z materią (por. Mt 11,19). Daleki był od pogardy wobec ciała i materii. Jako „cieśla, syn Maryi” (Mk 6,3) Jezus znał pracę fizyczną. Poprzez nią, zgodnie z nakazem starotestamentowym, przekształcał świat, czyniąc go sobie poddanym. Swoimi rzemieślniczymi umiejętnościami kształtował materię stworzoną. Zadanie to pochłonęło większość jego ludzkiego życia. Papież Franciszek, powołując się na św. Jana Pawła II, podkreśla, że Syn Człowieczy, poprzez wykonywaną przez siebie pracę, uświęcił ludzki wysiłek pracowniczy, a każdy, kto znosi trud pracy w zjednoczeniu z Chrystusem, staje się swego rodzaju współpracownikiem Jezusa w dziele zbawienia świata.

Druga Osoba Boska - Odwieczny Logos, który jest źródłem sensu istnienia świata, poprzez wcielenie złączył się ze swoim stworzeniem. W szczególny sposób uświęcił on materię i nadał jej wartość, czego fizycznym znakiem jest ludzie ciało Jezusa Chrystusa. Ponieważ przez ludzki grzech doszło do zaburzenia relacji pomiędzy Bogiem, człowiekiem i przyrodą, Chrystus dokonuje dzieła odkupienia. Zmartwychwstałe ciało Pana wskazuje na przyszłą rzeczywistość całego stworzenia, które przemienione zostaje mocą rezurekcji Chrystusa i zyskuje wartość większą niż w momencie stworzenia. Zmartwychwstanie ukierunkowuje całe stworzenie na przyszłą pełnię, która zrealizuje się na końcu czasów. Jezus, przebywając na świecie, nie stronił również od wszystkiego, co było związane z przyrodą i materialnym wymiarem życia człowieka. Poprzez swoją pracę przekształcał na ludzki sposób świat stworzony. Wykazywał się kontemplacyjną postawą wobec świata oraz trwał w serdecznej relacji ze środowiskiem naturalnym.

\footnotetext{
${ }^{33}$ Tamże.
} 


\section{BIBLIOGRAFIA}

Balter, Lucjan. „Nadzieja życia wiecznego skonkretyzowana w śmierci i zmartwychwstaniu Chrystusa". Communio 4(1984), 4: 74-94.

Batorski, Roman. „Encyklika Laudato si’ czytana przez biblistę”. W Kościót i nauka w obliczu ekologicznych wyzwań. Źródta, inspiracje i konteksty encykliki Laudato si', red. Jacek Poznański, Stanisław Jaromi, 93-106. Kraków: Wydawnictwo WAM, 2016.

Benedykt XVI. Dziękujmy Bogu za cud wcielenia: homilia podczas nieszporów w Bazylice Zwiastowania Pańskiego. Dostęp 06.03.2020, https://opoka.org.pl/biblioteka/W/WP/benedykt_xvi /homilie/zsw_nazaret_nieszp_14052009.html.

Benedykt XVI. Tajemnica Boga, który ma ręce i serce człowieka. Dostęp 05.03.2020, https://opoka.org.pl/biblioteka/W/WP/benedykt_xvi/audiencje/ag_09012013.html).

Dańczak, Andrzej. „Nadzieja zakotwiczona w Bogu. O eschatologii encykliki «Spe salvi»”, Studia Gdańskie 23(2008): 77-93.

Dańczak, Andrzej. „Zmartwychwstanie umarłych jako jeden z dynamicznych wymiarów eschatologii”. Verbum Vitae 15(2009): 343-368.

Dola, Tadeusz. Teologia misteriów życia Jezusa. Opole: Wydział Teologiczny Uniwersytetu Opolskiego, 2002.

Franciszek. Laudato si', encyklika poświęcona trosce o wspólny dom. Kraków: Wydawnictwo M, 2015.

Kijas, Zdzisław. Początki świata i człowieka. Kraków: Wydawnictwo WAM, 2004.

Langkammer, Hugolin. Życie człowieka w świetle Biblii. Antropologia biblijna Starego i Nowego Testamentu. Rzeszów: Poligrafia Wyższego Seminarium Duchownego, 2004.

Malina, Artur. „Dlaczego Jezus był ze zwierzętami (Mk 1,13)? Odniesienie do zwierząt w Ewangelii Markowej”. Verbum Vitae 32(2017): 233-254.

Mastej, Jacenty. Staurologiczo-rezurekcyjna wiarygodność chrześcijaństwa. Lublin: Wydawnictwo KUL, 2009.

Muszala, Andrzej. „Kwestie bioetyczne w encyklice «Laudato si’» papieża Franciszka”. Polonia Sacra 20(2016), 3: 39-65.

Ratzinger, Joseph. Bóg i świat. Wiara i życie w dzisiejszych czasach. Kraków: Znak, 2001.

Rogowski, Roman. Zwierzęta - nasi mniejsi bracia. Dostęp 03.03.2020, http://wiez.com.pl/2018 /02/09/zwierzeta-nasi-mniejsi-bracia/.

Rusecki, Marian. Pan zmartwychwstat i żyje: zarys teologii rezurekcyjnej. Warszawa: Instytut Wydawniczy PAX, 2006.

Rusecki, Marian. Traktat o Objawieniu. Kraków: Wydawnictwo Księży Sercanów, 2007.

Seweryniak, Henryk. Świadectwo i sens. Teologia fundamentalna. Płock: Płocki Instytut Wydawniczy, 2001.

Szymik, Jerzy. „Teologia wcielenia dzisiaj”. Ślaskie Studia Historyczno-Teologiczne 47(2014), 2 : 292-305.

Śmigiel, Wiesław. Uczestnictwo wiernych świeckich w budowaniu Kościoła-Wspólnoty. Studium teologicznopastoralne w świetle nauczania Kościoła (1962-2009). Lublin: Wydawnictwo KUL, 2010.

Wilczkiewicz, Krzysztof. „Ekologia i zmartwychwstanie. Rezurekcyjna przemiana człowieka i świata jako podstawa proekologicznej troski Kościoła”. Rocznik Kolbuszowski 17(2017): 453-460. 


\title{
CHRYSTOLOGICZNE PODSTAWY PROEKOLOGICZNEJ DZIAŁALNOŚCI KOŚCIOŁA
}

\author{
Streszczenie
}

Współczesny świat dotknięty został kryzysem ekologicznym, który stanowi wyzwanie dla całej rodziny ludzkiej, a jednocześnie znak czasu. Również Kościół katolicki angażuje się w jego przezwyciężenie, zwłaszcza poprzez działalność katolików świeckich, kształtujących porządek doczesny. Chrześcijanie odnajdują w swojej wierze nadprzyrodzoną motywację do troski o stworzony świat. Jest nią Osoba i dzieło samego Jezusa Chrystusa. Poprzez swoje wcielenie wszedł on w świat materialny, przebóstwiając go. Dokonując dzieła zbawienia, wyzwolił od zepsucia grzechu nie tylko ludzi wszystkich czasów, lecz całe stworzenie. Przebywając na świecie, w trakcie swojego ziemskiego życia, obcował z przyrodą i korzystał z niej w moralnie godziwy sposób. Wcielenie, odkupienie i postawa Jezusa stanowią więc ważną przesłankę dla działania całego Kościoła.

Słowa kluczowe: Jezus Chrystus; stworzenie; Kościół; ekologia. 